\title{
Penyisipan Media Teks dan Citra Menggunakan Teknik Steganografi pada Media Pembawa Citra Digital
}

\author{
Alim Muadzani *), Oky Dwi Nurhayati, Ike Pertiwi Windasari \\ Program Studi Sistem Komputer, Fakultas Teknik, Universitas Diponegoro \\ Jl. Prof. Soedarto, SH, Kampus Undip Tembalang, Semarang, Indonesia 50275
}

\begin{abstract}
Information has now become an important comodity in human life, with the rapid development of communications technology has enable people to communicate and exchange information more easily. Internet is very popular and used by billions users worldwide, the information passing through the internet is very large, and some certain people trying to get this information for profit. The information need to be secured to prevent the others to get the information that send through the internet, steganography can be used to hide the information before sending it and the receiver can recover the hidden data. Digital steganography using computer can use a variety of digital file, digital image file is one of them. With the infomation being hidden inside the image-carrier, the others will not aware about the hidden information. Application created using C\# programming leanguage and the steganoraphy method using Least Significant Bit Insertion (LSBI). Microsoft Visual Studio used as Integrated Development Environtment (IDE) to code and design the user interface. Software develpment model using Extreme Programming, and the testing using black box method. Application designed to hide text or image inside an image-carrier and the hidden text or image can be recovered. The result of this research are an application that can hide text or image into image-carrier, and the hidden text or image can be recovered. Based on the testing application can run as expected and fulfill all the requirements.
\end{abstract}

Keywords - C\#; Least Significant Bit; Steganography; image processing; JTSiskom

\section{Pendahuluan}

Teknologi telah memudahkan manusia untuk dapat saling berkomunikasi salah satunya dengan menggunakan internet, internet adalah seluruh jaringan komputer yang saling terhubung menggunakan standar sistem global (TCP/IP) sebagai protokol pertukaran paket. Pengguna internet berjumlah miliaran di seluruh dunia dan informasi yang lewat melalui internet sangat besar, hal ini menyebabkan beberapa pihak berusaha untuk mencuri informasi tersebut demi kepentingan tertentu. Informasi dapat terancam oleh interruption, interception, modification, dan fabrication ${ }^{[1]}$. Pengiriman informasi rahasia melalui internet harus diamankan agar informasi tersebut tidak jatuh kepada pihak yang tidak berhak. Informasi rahasia dapat disembunyikan kedalam suatu berkas digital salah satunya adalah citra digital. Dengan menggunakan teknik steganografi citra digital yang mengandung informasi tersembunyi tidak akan menarik

*) Penulis korespondensi

Email: alim.spectre@gmail.com perhatian oleh pihak yang berusaha mencuri informasi tersebut saat dikirimkan melalui internet.

Penelitian ini bertujuan untuk mengembangkan suatu aplikasi perangkat lunak desktop yang dapat menyisipkan suatu data berupa teks pesan maupun citra digital pesan kedalam citra digital pembawa, serta dapat mengambil kembali data yang disisipkan. Citra digital yang digunakan dalam aplikasi berformat Portable Network Graphic (PNG), aplikasi ditargetkan untuk dapat berjalan dikomputer dengan Sistem Operasi minimal Microsoft Windows 7, metode steganografi yang digunakan dalam aplikasi adalah Least Significant Bit Insertion.

\section{Metode Penelitian}

Pengembangan aplikasi ini menggunakan Metodologi Pengembangan Extreme Programming yang terdiri atas tahap listening, designing, coding, dan testing.

\section{A. Analisis Kebutuhan Sistem}

\section{1) Analisis Kebutuhan Fungsional}

Analisis kebutuhan fungsional untuk menentukan fungsi dan fitur dari sistem yang akan dikembangkan, disamping fitur tambahan yang ada dalam sistem beberapa fungsi utama yang harus ada dalam sistem diantaranya adalah sebagai berikut :

a. Aplikasi dapat menyisipkan teks pesan kedalam citra digital pembawa.

b. Aplikasi dapat menyisipkan citra digital pesan kedalam citra digital pembawa.

c. Aplikasi dapat mengambil teks pesan yang disembunyikan didalam citra digital stego.

d. Aplikasi dapat mengambil citra digital pesan yang disembunyikan didalam citra digital stego.

2) Analisis Kebutuhan Non Fungsional

Analisis kebutuhan non fungsional untuk mementukan kualitas sistem berdasarkan beberapa parameter sebagai berikut :

a. Extensibility : kemudahan dalam penambahan fitur baru tanpa perubahan besar yang mempengaruhi sistem.

b. Robustness : aplikasi dapat mengatasi error yang diakibatkan oleh kesalahan penggunaan, serta sistem menampilkan informasi mengenai pesan error tersebut secara akurat.

c. Usability : sistem dapat dengan mudah digunakan serta pengguna dapat dengan cepat familiar dengan fitur dan tampilan antarmuka.

d. Performance : sistem dapat beroperasi dengan handal.

3) Analisis Kebutuhan Pengembangan Sistem 
Perangkat lunak yang digunakan untuk penelitian dan pembuatan aplikasi adalah :

a. Sistem Operasi Microsoft Windows 8 Pro 64 bit.

b. Microsoft Visual Studio 2013, digunakan untuk menuliskan kode program serta sebagai compiler.

c. Inkscape, digunakan untuk membuat ikon yang digunakan dalam perangkat lunak, serta untuk merancang desain antarmuka aplikasi.

d. ClickCharts, digunakan untuk pembuatan diagram alir dan diagram blok aplikasi.

e. Dr.Explain, digunakan untuk membuat berkas panduan penggunaan aplikasi.

Perangkat keras yang digunakan untuk penelitian dan pembuatan aplikasi adalah :

a. Laptop Asus A42F dengan spesifikasi Processor Intel (R) Core (TM) i3 M330 @ 2.13 GHz, RAM 4GB, dengan Sistem Operasi Windows 8 Pro 64bit. Perangkat ini digunakan dalam proses pembuatan perangkat lunak.

\section{B. Perancangan Sistem}

Dalam penelitian ini perancangan sistem berupa perancangan diagram blok algoritma program yang menjelaskan proses operasi suatu fungsi, dan perancangan diagram alir perangkat lunak yang menunjukkan proses operasi aplikasi keseluruhan dari awal hingga akhir.

\section{1) Diagram Blok Algoritma Program}

Diagram blok proses penyisipan citra digital pesan kedalam citra digital pembawa ditunjukkan seperti pada Gambar 2.

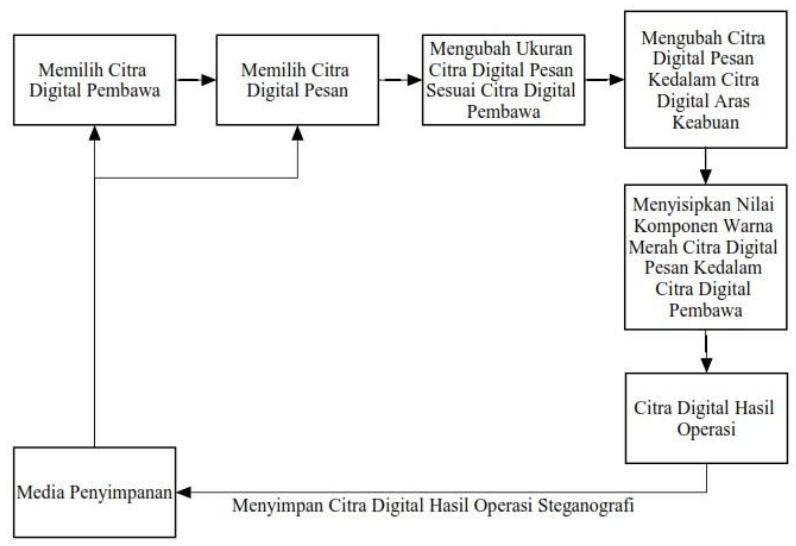

Gambar 2. Diagram blok proses penyisipan citra digital pesan

Pada diagram blok sistem proses penyisipan citra digital pesan kedalam citra digital pembawa, terlebih dahulu dengan memilih citra digital pembawa dan kemudian memilih citra digital pesan. Citra digital pesan yang telah dipilih selanjutnya akan dirubah ukurannya sesuai dengan ukuran dari citra digital pembawa dan kemudian dirubah kedalam citra digital aras keabuan. Proses pengubahan citra digital pesan menjadi citra digital aras keabuan dengan cara merata-rata nilai dari komponen warna merah, hijau dan biru dari setiap piksel yang ada dalam citra digital pesan. Citra digital pesan aras keabuan yang diperoleh setiap pikselnya komponen warna merah, hijau dan biru bernilai sama, kemudian nilai komponen warna merah digunakan untuk disisipkan kedalam citra digital pembawa. Pada proses penyisipan nilai warna merah dari citra digital pesan aras keabuan dirubah kedalam nilai biner yang bisa bernilai antara 00000000 sampai 11111111. Nilai biner tersebut akan disisipkan kedalam komponen alfa, warna merah, warna hijau, warna biru dari setiap piksel yang ada didalam citra digital pembawa, sehingga setiap komponen akan mendapat sisipan dua nilai baru yang akan disimpan dalam bit ketujuh dan kedelapan. Setelah itu akan didapatkan citra digital baru hasil operasi steganografi yang akan ditampilkan oleh aplikasi beserta informasi waktu yang dibutuhkan untuk melakukan proses penyisipan.

Diagram blok proses ekstraksi citra digital pesan dari citra digital stego ditunjukkan seperti pada Gambar 3.

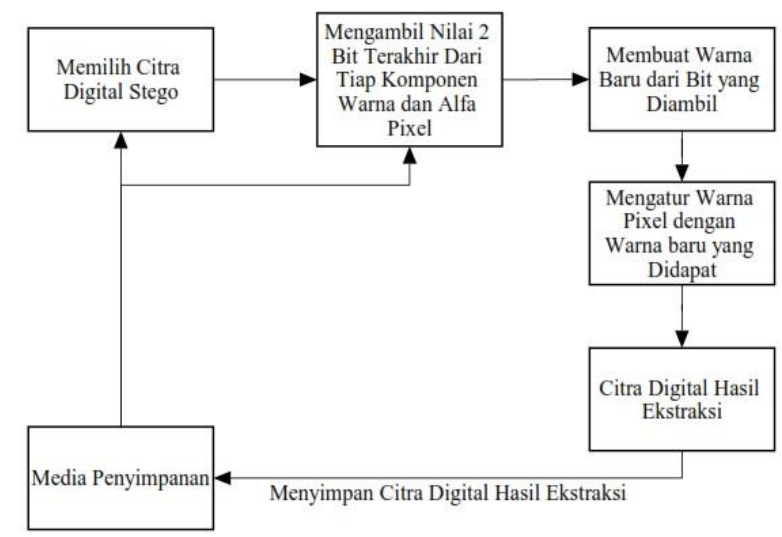

Gambar 3. Diagram blok proses ekstraksi citra digital pesan

Pada diagram sistem proses ekstraksi citra digital pesan akan diambil 2 bit terakhir dari komponen alfa, warna merah, warna hijau dan warna biru dari setiap piksel dari citra digital stego. Proses selanjutnya dengan menyusun 8 bit yang telah diambil dari citra digital stego dan mengubahnya menjadi bilangan angka lalu mengisikan nilai tersebut pada komposisi warna merah, hijau dan biru. Warna baru yang didapat akan disusun kembali menjadi sebuah citra digital baru dengan posisi piksel yang sama denga posisi piksel yang diambil informasinya. Nilai angka yang didapat bisa bernilai 0 sampai 255, dan dari komponen warna merah, hijau dan biru memiliki nilai yang sama maka nantinya akan didapatkan citra digital hasil dalam bentuk aras keabuan setelah semua piksel citra digital stego diproses dengan cara yang sama.

Diagram blok proses penyisipan teks pesan kedalam citra digital pembawa ditunjukkan seperti pada Gambar 4. Pada diagram blok sistem proses penyisipan teks pesan kedalam citra digital pembawa, terlebih dahulu dengan memilih citra digital pembawa dan kemudian memilih teks pesan atau mengetikkannya. Proses penyisipan dimulai dengan mendapatkan nilai ASCII dari karakter pesan, lalu merubahnya dalam bentuk 8 bit, setiap 1 bit nilai akan disisipkan kedalam Least Significant Bit 3 komponen warna dari 3 buah piksel yaitu Merah1, Hijau1, Biru1, Merah2, Hijau2, Biru2, 
Merah3, Hijau3. Proses ini akan berulang sebanyak jumlah karakter pesan yang ada didalam pesan, setelah semua karakter dalam pesan selesai disisipkan selanjutnya akan diberikan penanda akhir dari pesan yaitu 8 bit nilai yang bernilai 0, 00000000 akan disisipkan kedalam Least Significant Bit dari komponen warna 3 buah piksel yaitu Merah1, Hijau1, Biru1, Merah2, Hijau2, Biru2, Merah3, Hijau3. Hal ini dilakukan agar saat proses ekstraksi pesan nantinya jika pesan yang disembunyikan adalah pesan yang cukup pendek saat proses ekstraksi menemukan nilai 8 bit 00000000 maka proses akan dihentikan dan tidak perlu untuk mencoba proses ekstraksi seluruh citra digital stego. Citra digital hasil operasi penyisipan selanjutnya dapat disimpan kedalam media penyimpanan.

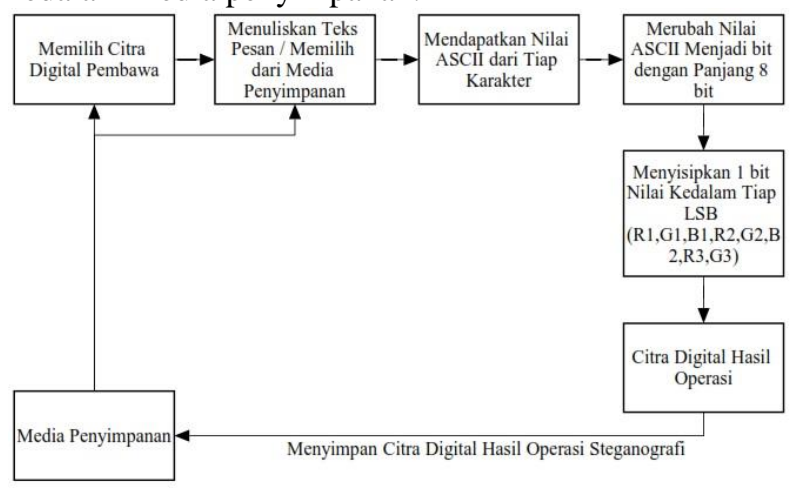

Gambar 4. Diagram blok proses penyisipan teks pesan

Diagram blok proses ekstraksi teks pesan dari citra digital stego ditunjukkan seperti pada Gambar 5.

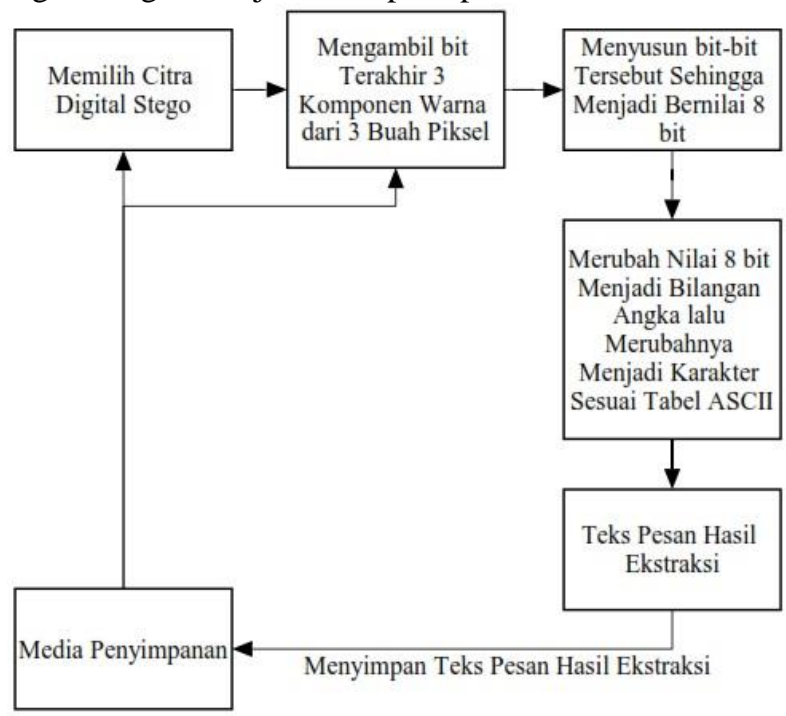

Gambar 5. Diagram blok proses ekstraksi teks pesan

Pada diagram sistem proses ekstraksi teks pesan akan diambil bit terakhir dari komponen warna merah, hijau dan biru dari 3 buah piksel, kemudian tiap 8 bit yang didapat akan dirubah kedalam bentuk karakter sesuai dengan nilai ASCII bilangan tersebut dan akan terus berulang sampai piksel terakhir atau menemukan nilai 8 bit 00000000. Setelah proses ekstraksi selesai akan didapatkan pesan tersembunyi hasil ekstraksi yang kemudian dapat disimpan kedalam media penyimpanan.

\section{2) Diagram Alir Aplikasi}

Gambar 6 dan 7 menunjukkan diagram alir aplikasi pengolahan citra digital dengan teknik steganografi.

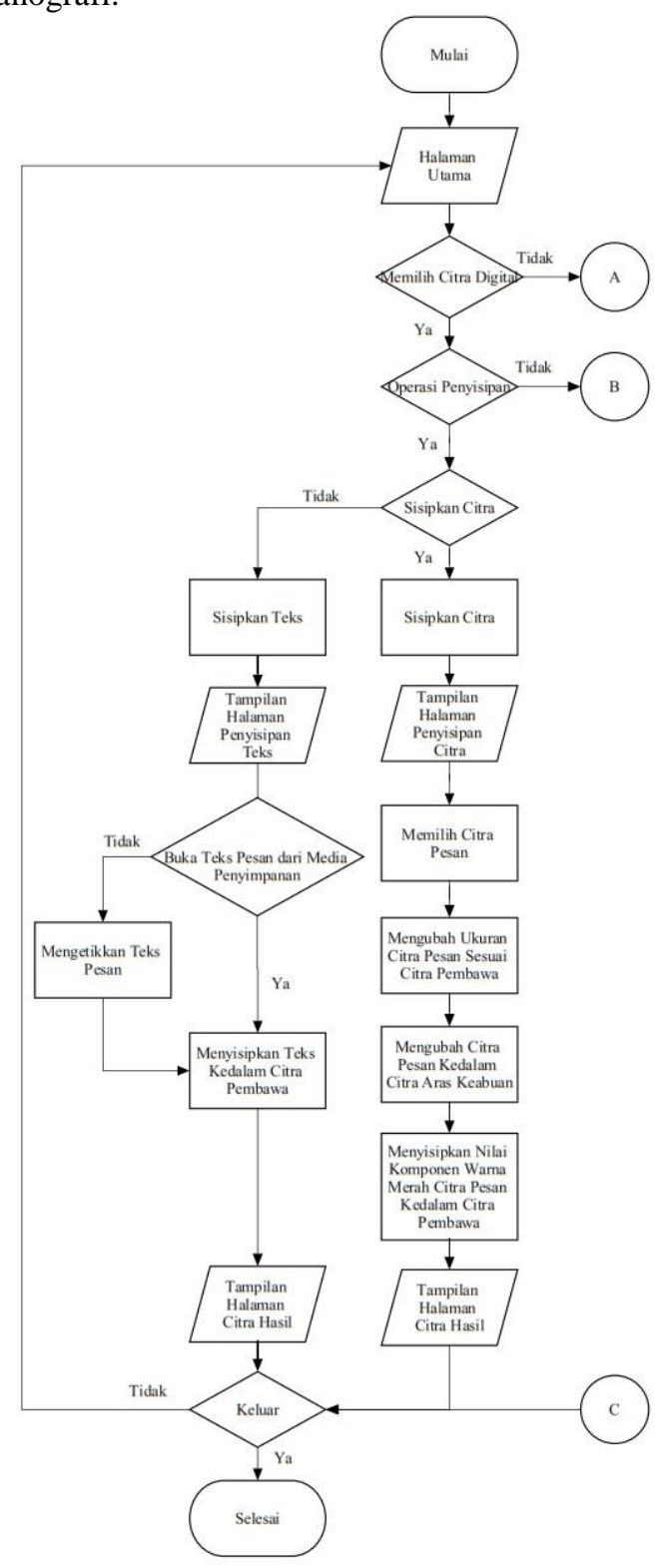

Gambar 6. Diagram alir aplikasi

Diagram alir yang dirancang merupakan prosesproses yang berjalan didalam aplikasi saat beroperasi dari saat aplikasi dimulai hingga aplikasi ditutup. Pada halaman utama terdapat pilihan untuk memilih gambar dari media penyimpanan dan tempel yang memiliki fungsi untuk memasukkan citra digital kedalam aplikasi untuk digunakan pada proses pengolahan. Pilihan potong dan salin berfungsi untuk menempatkan citra digital dari aplikasi kedalam clipboard untuk keperluan tempel. Pilihan operasi pengolahan citra digital yang tersedia adalah menyisipkan teks, ekstraksi teks, menyisipkan citra dan ekstraksi citra. Bantuan digunakan untuk melihat panduan penggunaan aplikasi serta menampilkan informasi tentang pengembang aplikasi. Zoom digunakan 
untuk memperbesar dan memperkecil tampilan citra digital yang dipilih.

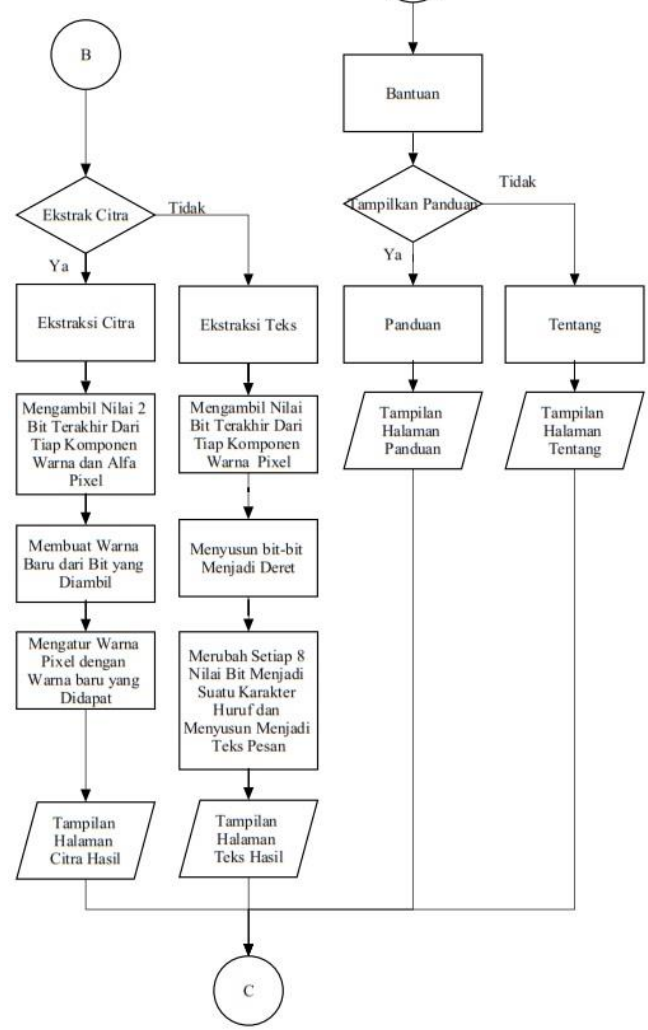

Gambar 7. Diagram alir aplikasi

Proses penyisipan teks dimulai dengan terlebih dahulu memilih suatu citra digital pembawa yang dapat dipilih dari media penyimpan, kemudian memilih operasi Sisipkan Teks setelah itu akan muncul tampilan halaman Penyisipan Teks. Pada halaman Penyisipan Teks pengguna bisa mengetikkan teks secara langsung, memilih suatu berkas teks berformat text (Txt) atau menempelkan teks yang telah tersimpan dalam clipboard. Setelah pengguna memilih tombol Sisipkan selanjutnya akan muncul tampilan halaman Hasil Penyisipan Teks, pada halaman ini akan menampilkan citra digital stego yang telah disisipi teks pesan, pengguna selanjutnya dapat menyimpan citra digital stego hasil operasi kedalam media penyimpanan.

Proses ekstraksi teks dimulai dengan terlebih dahulu memilih suatu citra digital stego kemudian memilih operasi Ekstraksi Teks setelah itu akan muncul tampilan halaman Hasil Ekstraksi Teks yang menampilkan teks tersembunyi yang didapatkan dari citra digital stego, pengguna selanjutnya dapat menyimpan pesan tersebut kedalam media penyimpanan.

Proses penyisipan citra digital dimulai dengan terlebih dahulu memilih citra digital pembawa kemudian memilih operasi Sisipkan Citra setelah itu akan muncul tampilan halaman Penyisipan Citra. Pada halaman Penyisipan Citra pengguna memilih citra digital pesan yang akan disispkan kedalam citra digital pembawa. Setelah pengguna memilih tombol Sisipkan selanjutnya akan muncul tampilan halaman Hasil pada halaman ini akan menampilkan citra digital yang telah disisipi citra digital pesan, pengguna selanjutnya dapat menyimpan citra digital stego hasil operasi kedalam media penyimpanan.

Proses ekstraksi citra digital dimulai dengan terlebih dahulu memilih suatu citra digital stego kemudian memilih operasi Ekstraksi Citra setelah itu akan muncul tampilan halaman Hasil Ekstraksi Citra yang menampilkan citra digital tersembunyi yang didapatkan dari citra digital stego, pengguna selanjutnya dapat menyimpan citra digital tersebut kedalam media penyimpanan.

Pilihan Panduan berisi panduan penggunaan aplikasi sedangkan pilihan Tentang akan menampilkan tampilan halaman Tentang yang berisi informasi pengembang aplikasi.

\section{HASIL DAN PEMBAHASAN}

\section{A. Tahap Penulisan Kode Program}

Penulisan kode program program dilakukan menggunakan IDE Microsoft Visual Studio, potongan kode program terdapat dalam lampiran.

\section{B. Pengujian Aplikasi}

Pengujian yang dilakukan pada system menggunakan metode black box. Pada tabel 1 merupakan pengujian black box pada sistem pengolahan data citra digital dengan teknik steganografi.

Tabel 1. Pengujian black box

\begin{tabular}{|c|c|c|c|}
\hline $\begin{array}{c}\text { Antarm } \\
\text { uka }\end{array}$ & $\begin{array}{c}\text { Fungsi } \\
\text { Yang } \\
\text { Diuji }\end{array}$ & Detail Uji & $\begin{array}{c}\text { Hasil } \\
\text { Uji }\end{array}$ \\
\hline \multirow[t]{4}{*}{$\begin{array}{l}\text { Halaman } \\
\text { Utama }\end{array}$} & $\begin{array}{l}\text { Tombol } \\
\text { Buka }\end{array}$ & $\begin{array}{l}\text { Membuka citra } \\
\text { digital dari } \\
\text { dalam media } \\
\text { penyimpanan } \\
\text { serta } \\
\text { menampilkan } \\
\text { informasi nama, } \\
\text { ukuran dan } \\
\text { resolusinya. }\end{array}$ & Berhasil \\
\hline & $\begin{array}{l}\text { Tombol } \\
\text { Potong }\end{array}$ & $\begin{array}{l}\text { Memotong citra } \\
\text { digital yang } \\
\text { sedang dibuka } \\
\text { dan } \\
\text { menempelkanny } \\
\text { a ke clipboard. }\end{array}$ & Berhasil \\
\hline & $\begin{array}{l}\text { Tombol } \\
\text { Salin }\end{array}$ & $\begin{array}{l}\text { Menyalin citra } \\
\text { digital yang } \\
\text { sedang dibuka } \\
\text { dan } \\
\text { menempelkanny } \\
\text { a ke clipboard. }\end{array}$ & Berhasil \\
\hline & $\begin{array}{l}\text { Tombol } \\
\text { Tempel }\end{array}$ & $\begin{array}{l}\text { Menempelkan } \\
\text { citra digital dari } \\
\text { clipboard }\end{array}$ & Berhasil \\
\hline
\end{tabular}




\begin{tabular}{|c|c|c|c|}
\hline & & $\begin{array}{l}\text { kedalam } \\
\text { aplikasi. }\end{array}$ & \\
\hline & $\begin{array}{l}\text { Tombol } \\
\text { Sisipkan } \\
\text { Teks }\end{array}$ & $\begin{array}{l}\text { Menampilkan } \\
\text { halaman } \\
\text { penyisipan teks. }\end{array}$ & Berhasil \\
\hline & $\begin{array}{l}\text { Tombol } \\
\text { Ekstrak } \\
\text { Teks }\end{array}$ & $\begin{array}{l}\text { Menampilkan } \\
\text { halaman } \\
\text { ekstraksi teks. }\end{array}$ & Berhasil \\
\hline & $\begin{array}{l}\text { Tombol } \\
\text { Sisipkan } \\
\text { Citra } \\
\end{array}$ & $\begin{array}{l}\text { Menampilkan } \\
\text { halaman } \\
\text { penyisipan citra. }\end{array}$ & Berhasil \\
\hline & $\begin{array}{l}\text { Tombol } \\
\text { Ekstrak } \\
\text { Citra }\end{array}$ & $\begin{array}{l}\text { Menampilkan } \\
\text { halaman } \\
\text { ekstraksi citra. }\end{array}$ & Berhasil \\
\hline & $\begin{array}{l}\text { Tombol } \\
\text { Bantuan }\end{array}$ & $\begin{array}{l}\text { Menampilkan } \\
\text { panduan } \\
\text { penggunaan } \\
\text { aplikasi. }\end{array}$ & Berhasil \\
\hline & $\begin{array}{l}\text { Tombol } \\
\text { Tentang }\end{array}$ & $\begin{array}{l}\text { Menampilkan } \\
\text { halaman } \\
\text { tentang. }\end{array}$ & Berhasil \\
\hline & $\begin{array}{l}\text { Trackbar } \\
\text { Zoom }\end{array}$ & $\begin{array}{l}\text { Memperbesar } \\
\text { atau } \\
\text { memperkecil } \\
\text { citra digital yang } \\
\text { sedang dibuka. }\end{array}$ & Berhasil \\
\hline $\begin{array}{l}\text { Halaman } \\
\text { Penyisip } \\
\text { an Citra }\end{array}$ & $\begin{array}{l}\text { Tombol } \\
\text { Buka }\end{array}$ & $\begin{array}{l}\text { Membuka citra } \\
\text { digital dari } \\
\text { dalam media } \\
\text { penyimpanan } \\
\text { serta } \\
\text { menampilkan } \\
\text { informasi nama, } \\
\text { ukuran dan } \\
\text { resolusinya. }\end{array}$ & Berhasil \\
\hline & Tombol & Menyimpan & Berhasil \\
\hline & Simpan & $\begin{array}{l}\text { Citra digital } \\
\text { kedalam media } \\
\text { penyimpanan. }\end{array}$ & \\
\hline & $\begin{array}{l}\text { Tombol } \\
\text { Potong }\end{array}$ & $\begin{array}{l}\text { Memotong citra } \\
\text { digital yang } \\
\text { sedang dibuka } \\
\text { dan } \\
\text { menempelkanny } \\
\text { a ke clipboard. }\end{array}$ & Berhasil \\
\hline & $\begin{array}{l}\text { Tombol } \\
\text { Salin }\end{array}$ & $\begin{array}{lr}\text { Menyalin citra } \\
\text { digital yang } \\
\text { sedang dibuka } \\
\text { dan } \\
\text { menempelkanny } \\
\text { a ke clipboard. }\end{array}$ & Berhasil \\
\hline & $\begin{array}{l}\text { Tombol } \\
\text { Tempel }\end{array}$ & $\begin{array}{l}\text { Menempelkan } \\
\text { citra digital dari } \\
\text { clipboard } \\
\text { kedalam } \\
\text { aplikasi. }\end{array}$ & Berhasil \\
\hline & $\begin{array}{l}\text { Tombol } \\
\text { Sisipkan }\end{array}$ & $\begin{array}{l}\text { Menampilkan } \\
\text { halaman hasil. }\end{array}$ & Berhasil \\
\hline & $\begin{array}{l}\text { Tombol } \\
\text { Panduan }\end{array}$ & $\begin{array}{l}\text { Menampilkan } \\
\text { panduan }\end{array}$ & Berhasil \\
\hline
\end{tabular}

\begin{tabular}{|c|c|c|c|}
\hline & & $\begin{array}{l}\text { penggunaan } \\
\text { aplikasi. }\end{array}$ & \\
\hline & $\begin{array}{l}\text { Trackbar } \\
\text { Zoom }\end{array}$ & $\begin{array}{l}\text { Memperbesar } \\
\text { atau } \\
\text { memperkecil } \\
\text { citra digital yang } \\
\text { sedang dibuka. }\end{array}$ & Berhasil \\
\hline \multirow[t]{7}{*}{$\begin{array}{l}\text { Halaman } \\
\text { Penyisip } \\
\text { an Teks }\end{array}$} & $\begin{array}{l}\text { Tombol } \\
\text { Buka }\end{array}$ & $\begin{array}{l}\text { Membuka } \\
\text { berkas teks dari } \\
\text { media } \\
\text { penyimpanan. }\end{array}$ & Berhasil \\
\hline & $\begin{array}{l}\text { Tombol } \\
\text { Simpan }\end{array}$ & $\begin{array}{l}\text { Menyimpan teks } \\
\text { kedalam media } \\
\text { penyimpanan. }\end{array}$ & Berhasil \\
\hline & $\begin{array}{l}\text { Tombol } \\
\text { Potong }\end{array}$ & $\begin{array}{l}\text { Memotong teks } \\
\text { dan } \\
\text { menempelkanny } \\
\text { a ke clipboard. }\end{array}$ & Berhasil \\
\hline & $\begin{array}{l}\text { Tombol } \\
\text { Salin }\end{array}$ & $\begin{array}{l}\text { Menyalin teks } \\
\text { dan } \\
\text { menempelkanny } \\
\text { a ke clipboard. }\end{array}$ & Berhasil \\
\hline & $\begin{array}{l}\text { Tombol } \\
\text { Tempel }\end{array}$ & $\begin{array}{l}\text { Menempelkan } \\
\text { teks dari } \\
\text { clipboard } \\
\text { kedalam } \\
\text { aplikasi. }\end{array}$ & Berhasil \\
\hline & $\begin{array}{l}\text { Tombol } \\
\text { Sisipkan }\end{array}$ & $\begin{array}{l}\text { Menampilkan } \\
\text { halaman hasil. }\end{array}$ & Berhasil \\
\hline & $\begin{array}{l}\text { Tombol } \\
\text { Panduan }\end{array}$ & $\begin{array}{l}\text { Menampilkan } \\
\text { panduan } \\
\text { penggunaan } \\
\text { aplikasi. }\end{array}$ & Berhasil \\
\hline \multirow{7}{*}{$\begin{array}{l}\text { Halaman } \\
\text { Hasil }\end{array}$} & Tombol & Menyimpan & Berhasil \\
\hline & Simpan & $\begin{array}{l}\text { Citra digital } \\
\text { kedalam media } \\
\text { penyimpanan. }\end{array}$ & \\
\hline & $\begin{array}{l}\text { Tombol } \\
\text { Potong }\end{array}$ & $\begin{array}{l}\text { Memotong citra } \\
\text { digital yang } \\
\text { sedang dibuka } \\
\text { dan } \\
\text { menempelkanny } \\
\text { a ke clipboard. }\end{array}$ & Berhasil \\
\hline & $\begin{array}{l}\text { Tombol } \\
\text { Salin }\end{array}$ & $\begin{array}{l}\text { Menyalin citra } \\
\text { digital yang } \\
\text { sedang dibuka } \\
\text { dan } \\
\text { menempelkanny } \\
\text { a ke clipboard. }\end{array}$ & Berhasil \\
\hline & $\begin{array}{l}\text { Tombol } \\
\text { Tempel }\end{array}$ & $\begin{array}{l}\text { Menempelkan } \\
\text { citra digital dari } \\
\text { clipboard } \\
\text { kedalam } \\
\text { aplikasi. }\end{array}$ & Berhasil \\
\hline & $\begin{array}{l}\text { Tombol } \\
\text { Panduan }\end{array}$ & $\begin{array}{l}\text { Menampilkan } \\
\text { panduan } \\
\text { penggunaan } \\
\text { aplikasi. }\end{array}$ & Berhasil \\
\hline & $\begin{array}{l}\text { Trackbar } \\
\text { Zoom }\end{array}$ & $\begin{array}{l}\text { Memperbesar } \\
\text { atau }\end{array}$ & Berhasil \\
\hline
\end{tabular}




\begin{tabular}{llll}
\hline & & $\begin{array}{l}\text { memperkecil } \\
\text { citra digital yang } \\
\text { sedang dibuka. }\end{array}$ & \\
\hline Halaman & Tombol & $\begin{array}{l}\text { Menampilkan } \\
\text { panduan }\end{array}$ & Berhasil \\
Tentang & Panduan & \\
& & $\begin{array}{l}\text { penggunaan } \\
\text { aplikasi. }\end{array}$ & \\
\hline
\end{tabular}

\section{Analisis Hasil Pengujian Fungsi}

Pengujian dilakukan untuk memastikan bahwa fungsi utama dalam aplikasi dapat berjalan dengan baik, pengujian yang dilakukan meliputi proses penyisipan teks dan citra digital serta proses ekstraksi teks dan citra digital.

\section{1) Penyisipan Teks Pesan}

Proses diawali dengan menjalankan aplikasi, pada tampilan antarmuka halaman utama pengguna kemudian memilih citra digital pembawa melalui pilihan tombol Buka, setelah itu pengguna memilih tombol Sisipkan Teks seperti yang ditunjukkan oleh Gambar 8 dan akan muncul antarmuka halaman untuk menyisipkan teks.

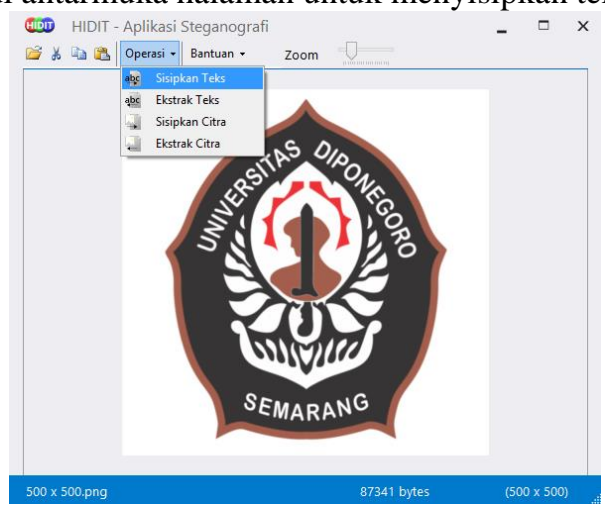

Gambar 8. Halaman utama

Pengguna kemudian mengetikkan teks pesan yang diinginkan, lalu pengguna memilih tombol Sisipkan seperti yang ditunjukkan oleh Gambar 9.

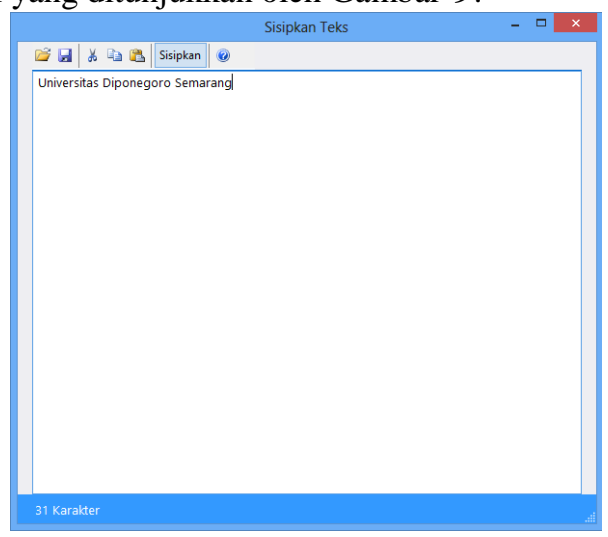

Gambar 9. Halaman penyisipan teks

Setelah proses penyisipan selesai aplikasi akan menampilkan citra hasil penyisipan teks pesan yang disebut sebagai citra digital stego seperti yang ditunjukkan oleh Gambar 10, selain itu aplikasi akan menampilkan informasi lama waktu operasi penyisipan, citra stego hasil operasi dapat disimpan kedalam media penyimpanan ataupun ditempelkan kedalam clipboard.

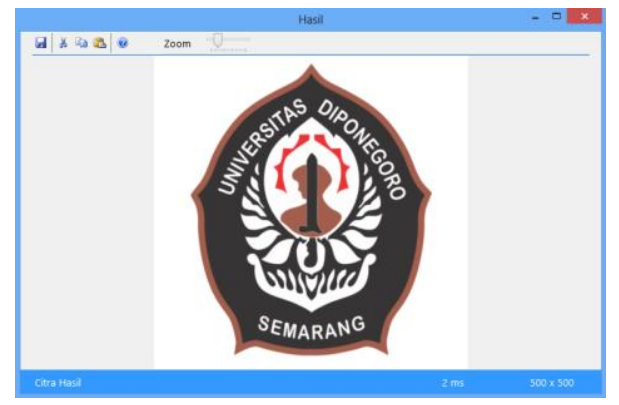

Gambar 10. Halaman Hasil

\section{2) Ekstraksi Teks Pesan}

Proses ekstraksi diawali dengan membuka citra digital stego kedalam aplikasi, kemudian pengguna memilih tombol Ekstrak Teks seperti yang ditunjukkan oleh Gambar 11. Gambar 12 menunjukan teks pesan yang berhasil didapatkan dari proses ekstraksi serta informasi lama waktu yang dibutuhkan untuk mengekstraksi pesan teks dari citra digital stego, teks pesan selanjutnya dapat disimpan kedalam media penyimpanan dengan format text (Txt) ataupun ditempelkan kedalam clipboard.

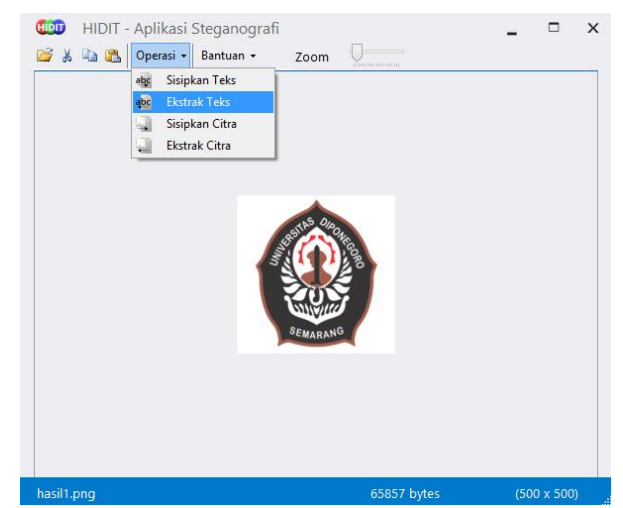

Gambar 11. Halaman Utama

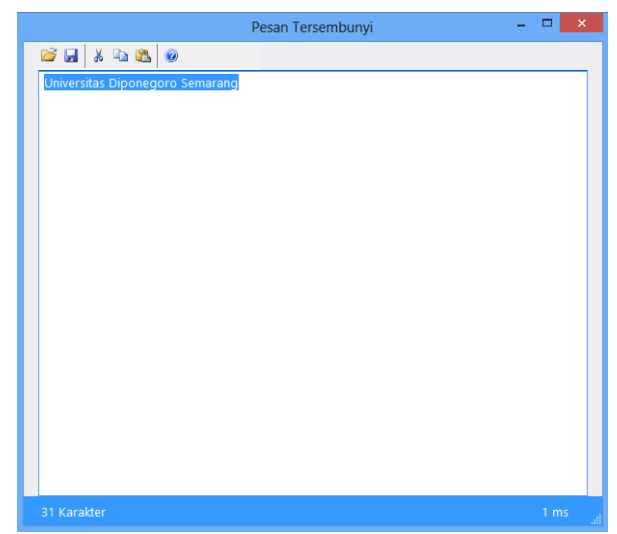

Gambar 12. Halaman Ekstraksi Teks

\section{3) Penyisipan Citra Digital Pesan}

Proses diawali dengan menjalankan aplikasi, pada tampilan antarmuka halaman utama penggguna kemudian membuka citra digital pesan kedalam aplikasi, selanjutnya pengguna memilih tombol Sisipkan Citra seperti yang ditunjukkan oleh Gambar 13, selanjutnya akan tampil antarmuka halaman penyisipan citra. 


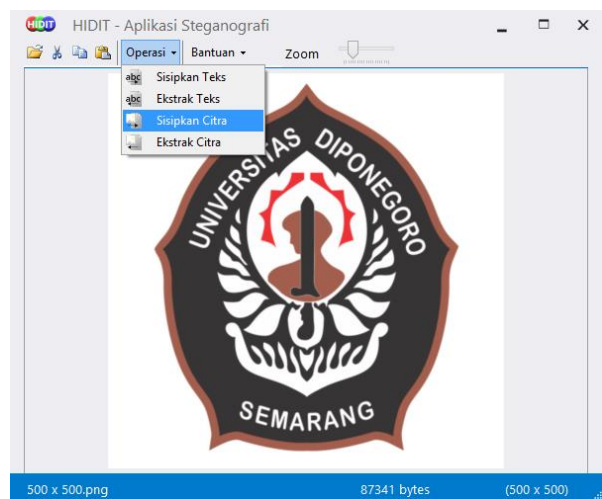

Gambar 13. Halaman Utama

Pengguna memilih citra digital pesan, kemudian memilih tombol Sisipkan seperti yang ditunjukkan oleh Gambar 14. Setelah proses penyisipan berakhir aplikasi akan menampilkan citra digital stego seperti yang ditunjukkan oleh Gambar 15.

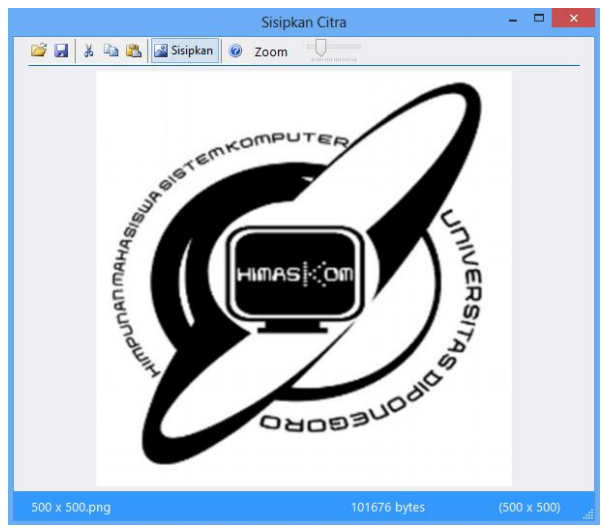

Gambar 14. Halaman Penyisipan Citra

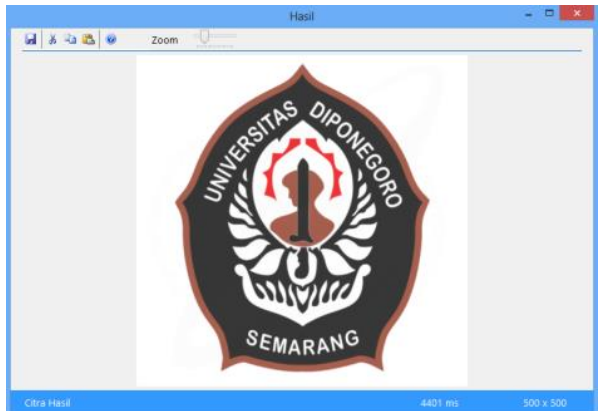

Gambar 15. Halaman Hasil

\section{4) Ekstraksi Citra Digital Pesan}

Proses diawali dengan menjalankan aplikasi lalu pengguna membuka citra digital stego kedalam aplikasi, dan kemudian memilih tombol Ekstrak Citra seperti yang ditunjukkan oleh Gambar 16, selanjutnya akan muncul tampilan antarmuka halaman ekstraksi citra. Citra digital stego kemudian akan diekstrak untuk didapatkan citra digital pesan seperti yang ditunjukkan oleh Gambar 17, akan ditampilkan pula informasi lama waktu yang dibutuhkan oleh aplikasi untuk melakukan proses ekstraksi citra digital pesan dari citra digital stego. Citra digital pesan yang didapatkan selanjutnya dapat disimpan kedalam media penyimpanan.

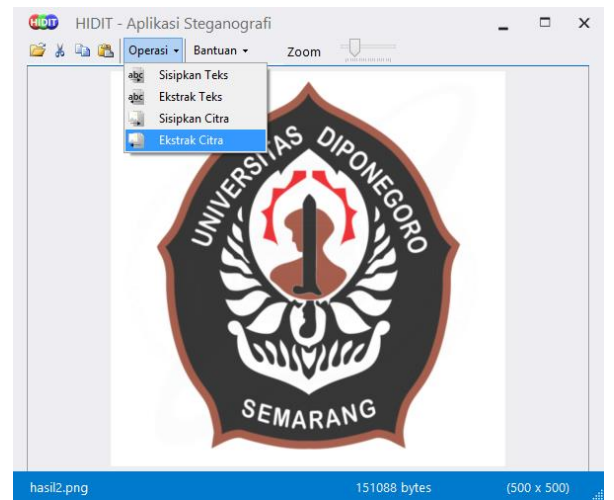

Gambar 16. Halaman Utama

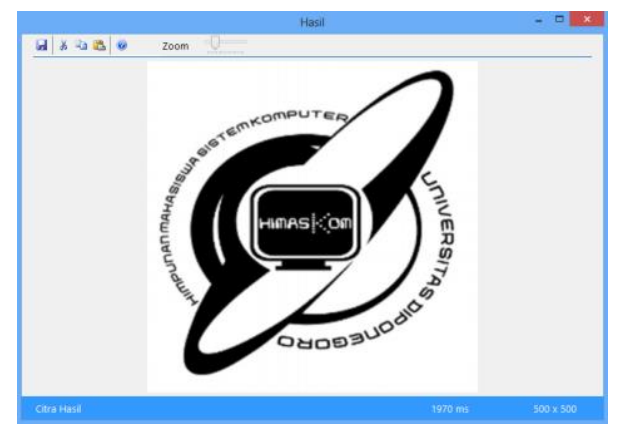

Gambar 17. Halaman Ekstraksi Citra

\section{Pengujian Lanjut}

1) Pengujian Lama Waktu Operasi

Pada tabel 2 menunjukkan hasil pengujian proses penyisipan citra digital pesan kedalam citra digital pembawa dengan beragam ukuran resolusi, dan pada tabel 3 menunjukkan hasil pengujian proses ekstraksi citra digital pesan dari citra digital stego. Pada tabel 4 menunjukkan hasil pengujian proses penyisipan teks pesan kedalam citra digital pembawa, dan tabel 5 menunjukkan hasil pengujian proses ekstraksi teks dari citra digital stego.

Tabel 2. Penyisipan citra digital

\begin{tabular}{ccc}
\hline $\begin{array}{c}\text { Ukuran resolusi } \\
\text { citra digital } \\
\text { pembawa } \\
\text { (panjang } \times \text { lebar) } \\
\text { dalam piksel }\end{array}$ & $\begin{array}{c}\text { Ukuran resolusi } \\
\text { citra digital } \\
\text { pesan (panjang } \\
\text { x lebar) dalam } \\
\text { piksel }\end{array}$ & $\begin{array}{c}\text { Lama } \\
\text { waktu } \\
\text { operasi } \\
\text { dalam } \\
\text { milidetik }\end{array}$ \\
\hline $100 \times 100$ & $750 \times 750$ & 205 \\
\hline $250 \times 250$ & $750 \times 750$ & 1179 \\
\hline $500 \times 500$ & $750 \times 750$ & 4538 \\
\hline $750 \times 750$ & $750 \times 750$ & 10416 \\
\hline $1000 \times 1000$ & $750 \times 750$ & 18719 \\
\hline $1250 \times 1250$ & $750 \times 750$ & 27962 \\
\hline $1500 \times 1500$ & $750 \times 750$ & 42442 \\
\hline
\end{tabular}

Tabel 3. Ekstraksi pesan citra digital

\begin{tabular}{cc}
$\begin{array}{c}\text { Ukuran resolusi citra digital stego } \\
\text { (panjang } \mathbf{x} \text { lebar) dalam piksel }\end{array}$ & $\begin{array}{c}\text { Lama } \\
\text { waktu } \\
\text { operasi } \\
\text { dalam } \\
\text { milidetik }\end{array}$ \\
\hline $100 \times 100$ & 98 \\
\hline
\end{tabular}




\begin{tabular}{ll}
\hline $250 \times 250$ & 501 \\
\hline $500 \times 500$ & 1945 \\
\hline $750 \times 750$ & 4435 \\
\hline $1000 \times 1000$ & 7883 \\
\hline $1250 \times 1250$ & 12868 \\
\hline $1500 \times 1500$ & 17963 \\
\hline
\end{tabular}

Tabel 4. Penyisipan teks pesan

\begin{tabular}{lll}
\hline $\begin{array}{c}\text { Ukuran } \\
\text { pesan dalam } \\
\text { Byte }\end{array}$ & $\begin{array}{c}\text { Ukuran resolusi } \\
\text { citra digital } \\
\text { pembawa (panjang } \\
\text { x lebar) dalam } \\
\text { piksel }\end{array}$ & $\begin{array}{c}\text { Lama } \\
\text { waktu } \\
\text { operasi } \\
\text { dalam } \\
\text { milidetik }\end{array}$ \\
\hline 509 & $750 \times 750$ & 2 \\
\hline 1024 & $750 \times 750$ & 4 \\
\hline 9869 & $750 \times 750$ & 45 \\
\hline 18349 & $750 \times 750$ & 81 \\
\hline 37455 & $750 \times 750$ & 168 \\
\hline 136454 & $750 \times 750$ & 660 \\
\hline 286927 & $750 \times 750$ & 941 \\
\hline
\end{tabular}

Tabel 5. Ekstraksi teks pesan

\begin{tabular}{lll}
\hline $\begin{array}{c}\text { Ukuran } \\
\text { pesan } \\
\text { dalam Byte }\end{array}$ & $\begin{array}{c}\text { Ukuran resolusi } \\
\text { citra digital stego } \\
\text { panjang x lebar) } \\
\text { dalam piksel }\end{array}$ & $\begin{array}{c}\text { Lama waktu } \\
\text { operasi dalam } \\
\text { milidetik }\end{array}$ \\
\hline 509 & $750 \times 750$ & 3 \\
\hline 1024 & $750 \times 750$ & 5 \\
\hline 9869 & $750 \times 750$ & 59 \\
\hline 18349 & $750 \times 750$ & 142 \\
\hline 37455 & $750 \times 750$ & 508 \\
\hline 136454 & $750 \times 750$ & 11097 \\
\hline 286927 & $750 \times 750$ & 28270 \\
\hline
\end{tabular}

\section{E. Analisis Penelitian}

Pengujian juga dilakukan dengan menggunakan beberapa citra digital pembawa serta citra digital pesan lain yang memiliki beragam ukuran resolusi dan sistem dapat berjalan dengan baik.

Lamanya waktu yang dibutuhkan untuk menyisipkan citra digital pesan dan lamanya waktu yang dibutuhkan untuk mengekstraksi citra digital pesan berbanding lurus dengan ukuran resolusi citra digital pembawa. Lamanya waktu yang dibutuhkan untuk menyisipkan teks pesan berbanding lurus dengan ukuran pesan yang disisipkan, semakin besar ukuran pesan maka semakin lama waktu operasi yang dibutuhkan sesuai dengan penelitian yang dilakukan oleh Praditya ${ }^{[2]}$.

Sesuai dengan penelitian yang dilakukan oleh Anwary ${ }^{[3]}$ citra digital stego yang dihasilkan melalui proses steganografi dengan menggunakan metode least significant bit insertion memiliki ketahanan yang rendah terhadap proses operasi manipulasi citra.

\section{KESIMPULAN}

Berdasarkan pengujian yang dilakukan, aplikasi yang dibuat dapat dijalankan pada perangkat komputer yang menggunakan Sistem Operasi Windows 7, Windows 8, Windows8.1 dan Windows 10, serta dapat menyisipkan informasi berupa teks pesan maupun citra digital pesan kedalam citra digital pembawa serta dapat mendapatkan informasi tersebut kembali. Citra digital stego yang dihasilkan memiliki ketahanan menjaga integritas informasi pesan yang rendah terhadap operasi editting dan compression. Semakin banyak teks pesan yang disembunyikan maka waktu operasi juga semakin banyak, semakin besar ukuran citra digital pembawa dalam proses penyisipan citra digital maka waktu operasi yang dibutuhkan juga semakin banyak.

Berdasarkan pengembangan dan pengujian yang telah dilakukan, saran untuk pengembangan aplikasi dikemudian hari dengan penambahan fitur agar pengguna dapat menentukan jumlah bit pada citra digital pembawa yang akan disisipi, penambahan fungsi kriptografi untuk meningkatkan keamanan data, serta penambahan berkas digital yang dapat disisipkan kedalam citra digital pembawa.

\section{UCAPAN TERIMA KASIH}

Terima kasih disampaikan kepada Program Studi Sistem Komputer Undip yang telah mendanai keberlangsungan jurnal ini.

\section{DAFTAR PUSTAKa}

[1] Dony, A., Kriptografi Keamanan Data Dan Komunikasi. Yogyakarta: Graha Ilmu, 2006.

[2] Praditya, D., “Aplikasi Steganografi Berbasis GUI Dengan Metode Penggantian LSB", Makalah Seminar Penelitian, Universitas Diponegoro, Semarang, 2011.

[3] Anwary, M. R. A., "Teknik Penyembunyian Data Rahasia Dengan Menggunakan Citra Digital Sebagai Berkas Penampung", Makalah Seminar Penelitian, Universitas Diponegoro, Semarang, 2007.

[4] Darma, P., Pengolahan Citra Digital, Yogyakarta, Penerbit ANDI, 2010.

[5] Hery, M. dan Purnomo, A. M., Konsep Pengolahan Citra Digital dan Ekstrasi Fitur. Yogyakarta: Graha Ilmu, 2010.

[6] Prayudi, Y. dan Rahmadhani B., "Steganography Menggunakan Teknik LSB pada Media Citra GIF," Media Informatika., vol.9, no. 9, 2003.

[7] Prayudi, Y. dan Kuncoro P. S., "Implementasi Steganografi Menggunakan Teknik Adaptive Minimum Error Least Significant Bit Insertion," Seminar Nasional Aplikasi Teknologi Informasi, Yogyakarta, 2005.

[8] Soplanit, S. dan Bandaria C., "Steganografi Dengan Chaotic Least Significant Bit Encoding Pada Telepon Genggam," Jurnal Informatika., vol. 8, no. 1, pp. 37-41, 2007.

[9] Nair, K., Karan A., and Jonathan J., "Implementing Semi-Blind Image Steganography with Improved Concealment," no. Icct, pp. 14-19, 2015. 
[10] Wijaya, E. S dan Y. Prayudi, “Konsep Hidden Message dengan Menggunakan Teknik Steganografi Dynamic Cell Spreading," Media Informatika., vol. 9, no. 9, pp. 231-245, 2007.

[11] Ferguson, J., B. Patterson, J. Beres, P. Boutquin, and M. Gupta, C \# Bible. 2002.
[12] Ostrand, T., "Black-Box Testing," Encycl. Softw. Eng., 2002.

[13] Anders, C. and K. Beck, Extreme Programming Explained. 2005. 